\title{
PERMASALAHAN \\ PADA PELAKSANAAN PEMBELAJARAN TERINTEGRASI DI PROGRAM STUDI PENDIDIKAN BAHASA JEPANG, UNDIKSHA
}

\author{
G. S. Hermawan, K. E. Krishna Adnyani \\ Jurusan Pendidikan Bahasa Jepang, Fakultas Bahasa dan Seni \\ Universitas Pendidikan Ganesha, Singaraja, Bali, Indonesia \\ Email: satya.hermawan@undiksha.ac.id², krishna.adnyani@undiksha.ac.id ${ }^{1}$
}

\begin{abstract}
The issue of integrated learning on the basic Japanese language skills, namely: Bunpou, Choukai, and Kaiwa, had been raised since the establishment of the Japanese Education Department. A recent evaluation study found that in the actual implementation of this integrated learning experience, a number of problems need to be considered for the quality of learning process in the Department of Japanese Language Education. The problems discussed in this paper are related to the implementation of integrated courses and the issues that follow. This research conducted in the Bunpou, Choukai, and Kaiwa classes in the 2016/2017. This study used a descriptive qualitative method with observation and interviews techniques. The results found that problems in implementing this integrated learning comprise: lecturers' communication skills, conflicted time with other activities, and different teaching themes from one lecturer to the other lecturers.
\end{abstract}

Keywords : Bunpou, Choukai, Kaiwa, integrated learning, Department of Japanese Language Education.

\section{ABSTRAK}

Ketika Jurusan Pendidikan bahasa Jepang akan dibentuk, telah dipikirkan untuk m e n e r a p $\mathrm{k}$ a n pembelajaran terintegrasi pada matakuliah kompetensi dasar berbahasa Jepang, yaitu : Bunpou, Choukai, dan Kaiwa. Setelah melakukan penelitian evaluasi ditemukan bahwa, dalam pelaksanaannya pelaksanaan pembelajaran terintegrasi ini mengalami permasalahan-permasalahan yang patut dipikirkan untuk keberlangsungan proses pembelajaran di lingkungan Jurusan Pendidikan Bahasa Jepang. Dengan ini maka permasalahan yang dibahas dalam penelitian ini adalah proses pelaksanaan matakuliah terintegrasi dan permasalahan-permasalahan yang mengikutinya. Penelitian ini dilakukan pada kelas Bunpou, Choukai, dan Kaiwa semester ganjil 2016/2017. Penelitian ini menggunakan metode deskriptif kualitatif dengan teknik simak dan catat, dan wawancara. Hasil yang ditemukan bahwa terdapatnya masalah ketika melaksanakan pembelajaran terintegrasi ini, yaitu: komunikasi dosen, waktu dan kegiatan lain, dan materi yang berbeda.

Kata kunci : Bunpou, Choukai, Kaiwa, pembelajaran terintegrasi, Jurusan Pendidikan Bahasa Jepang.

\section{PENDAHULUAN}

Pada tahun 2010 didirikan Jurusan Pendidikan Bahasa Jepang (kini Prodi Bahasa Jepang), kurikulum yang dibuat telah melalui berbagai macam evaluasi dan pengemban gan. Pada saat itu diputuskan untuk terdapat matakuliah kemampuan Bahasa Jepang (matakuliah konten) yang masuk ke dalam ma- takuliah kompetensi dasar berbahasa Jepang yang berprasyarat. Selain diputuskan untuk berprasyarat, setiap mata kuliah konten tersebut terintegrasi atau berhubungan satu dengan lainnya. Keputusan ini diambil, sejalan dengan pemikiran Mansilla (2008), yang menyatakan bahwa pembelajaran terintegrasi akan mampu membuat mahasiswa atau peserta didik berpikir kritis dan multidisiplin, sehingga mereka 
mampu memecahkan isu-isu yang kompleks. Sehingga atas dasar pemikiran tersebut maka menyebabkan masing-masing matakuliah kejepangan tersebut terhubung seperti gambar berikut.

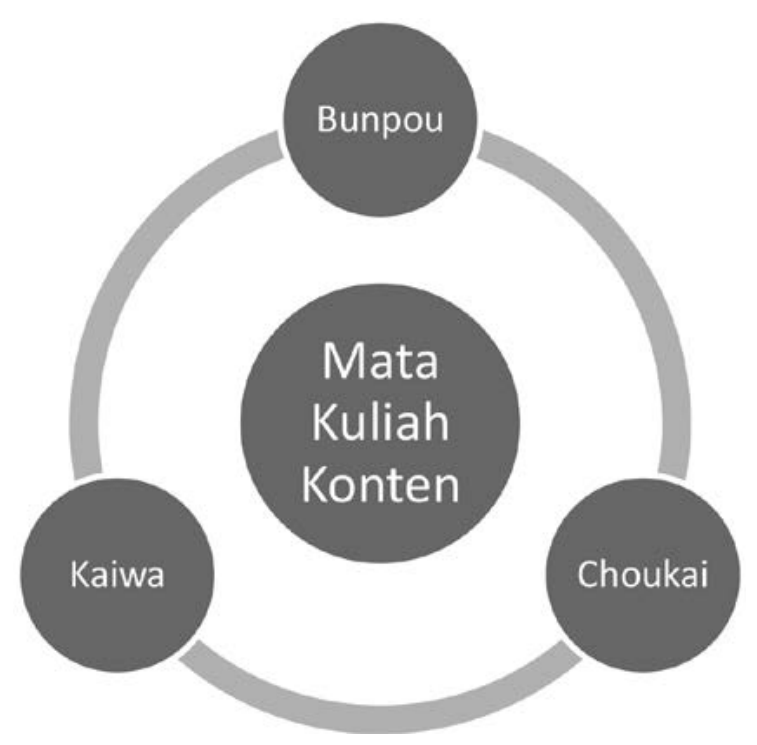

Gambar. 1. Hubungan antar matakuliah konten

Lalu, mata kuliah konten yang akan dibahas di sini yaitu文法 - bunpou- (tata bahasa), 聴解 -choukai- (mendengar), 会話 kaiwa- (berbicara).

a. 文法-bunpou- (tata bahasa)

Merupakan mata kuliah yang mengajarkan tata bahasa Jepang. Terdiri dari enam tingkat, yaitu dari Bunpou 1 sampai Bunpou 6. Mata kuliah ini adalah mata kuliah dasar bagi seluruh mata kuliah keahlian berbahasa Jepang.

\section{b. 聴解-choukai- (mendengar)}

Merupakan mata kuliah yang melatih kemampuan mendengar percakapan dan wacana bahasa Jepang. Terdiri dari lima tingkat, yaitu dari Choukai 1 sampai Choukai 5. Choukai 1 idealnya diberikan setelah mahasiswa menerima setidaknya satu kali pertemuan aktif Bunpou 1. Sehingga mahasiswa mampu melatih kemampuannya tidak berangkat dari nol.

\section{c. 会話-kaiwa- (berbicara)}

Merupakan mata kuliah yang melatih kemampuan berbicara bahasa Jepang. Terdiri dari empat tingkat, dari Kaiwa 1 sampai Kaiwa 4.
Lalu terdapat pula mata kuliah pilihan Kaiwa 5 dan Kaiwa 6. Kaiwa 1 juga idealnya dilaksanakan setelah menerima setidaknya satu kali pertemuan aktif kuliah Bunpou 1, sehingga mahasiswa bisa menggunakan penggunaan pola kalimat yang telah dipelajari.

Integrasi di sini memiliki arti satu matakuliah konten memiliki keterkaitan tema atau pola kalimat dengan matakuliah konten lainnya. Untuk ketiga matakuliah konten yang paling utama adalah Bunpou. Hal ini dikarenakan matakuliah konten tersebut mengajarkan kemampuan gramatika Bahasa Jepang. Dikarenakan bahasa Jepang merupakan bahasa asing yang tidak semua mahasiswa telah mempelajarinya di SMA. Sesuai dengan hasil wawancara dengan dosen pengampu matakuliah Bunpou, Kaiwa dan Choukai, sepakat menyatakan bahwa tata bahasa merupakan matakuliah yang utama, jika mahasiswa tidak memahami hal tersebut maka secara logis tidak akan memahami dalam penggunaannya, baik itu kemampuan mendengar/menyimak (choukai) maupun kemampuan berbicaranya (kaiwa).

Setelah berjalan dan dilaksanakan, sesuai dengan laporan dan pengamatan, dalam pelaksanaannya tidak sesuai dengan pelaksanaan pembelajaran terintegrasi yang diharapkan. Berdasarkan hasil wawancara dengan dosen pengampu matakuliah Choukai ditemukan bahwa, waktu mengajar dosen pengampu; kegiatan di luar akademik; hingga kegiatan mahasiswa dapat menghambat terjadinya pelaksanaan integrasi masing-masing matakuliah konten Bahasa Jepang. Dalam laporan ketika rapat jurusan, dosen mengampu harus berkejaran dengan waktu untuk mengampu matakuliah konten tersebut. Akibatnya sebagai contoh kasus dalam matakuliah Kaiwa yang sejatinya bertujuan untuk membantu mahasiswa dalam melatih kemampuan berbicara justru harus menjelaskan tata bahasanya karena dalam matakuliah Bunpou hal tersebut belum dijelaskan. Hal ini kemungkinan dapat menghambat atau membingungkan mahasiswa. Hal inilah yang menjadi latar belakang dilakukannya penelitian ini. 


\section{METODE}

Penelitian ini mempergunakan metode deskriptif kualitatif. Penelitian deskriptif kualitatif merupakan penelitian yang datanya berupa deskripsi berdasarkan hasil pengamatan di kelas Bunpou, Choukai, dan Kaiwa semester ganjil 2016/2017 di Jurusan Pendidikan Bahasa Jepang. Dalam penelitian ini, data diambil melalui teknik simak dan catat. Kemudian hasil dari pengamatan tersebut akan diperkuat melalui studi pustaka, dan ditambah dengan teknik wawancara.

Arifin (2010), menjelaskan bahwa evaluasi memiliki pengertian menilai atau menentukan nilai sesuatu. Lalu, evaluasi digunakan pada konteks yang lebih luas, dan biasanya dilakukan secara eksternal, seperti konsultan yang digunakan untuk mengevaluasi program, baik pada level terbatas maupun level yang luas. Saya menggarisbawahi dua hal dari pemaknaan Arifin tersebut, yang pertama adalah evaluasi merupakan penentuan nilai sesuatu yang digunakan pada konteks yang lebih luas. Kedua, biasanya dilakukan secara eksternal, karena terdapat kata 'biasanya', maka sebenarnya evaluasi pun dapat dilakukan secara internal, selama konteks digunakannya secara luas.

Kemudian, pembelajaran terintegrasi atau terpadu berangkat dari sebuah kurikulum yang dibuat secara holistik untuk satu tujuan yang sama. Mata kuliah yang berada di dalamnya, antara satu dengan lainnya memiliki keterkaitan dan fungsi masing-masing. Frazee dan Rudnitski (1995, dalam Rusman, 2015 :113) mengatakan kurikulum terpadu (integrated curriculum) pada dasarnya mengintegrasikan sejumlah disiplin, melalui keterkaitan di antara tujuan, isi, keterampilan, dan sikap.

Fogarty (1991), membagi kurikulum terintegrasi menjadi sepuluh model yang berdasarkan sifat keterpaduannya dikelompokkan menjadi tiga model besar. Ketiga model tersebut adalah.

a) model dalam satu disiplin ilmu yang meliputi model fragmen, keterhubungan (connected) dan model terangkai (nested). b) model antar bidang studi yang meliputi model urutan (sequenced), model perpaduan (shared), model jaring laba-laba (webbed), model bergalur (threaded) dan model terpadu (integrated).

c) model dalam dan lintas siswa yang meliputi model immersed dan model networked.

Jurusan Pendidikan Bahasa Jepang, Undiksha menerapkan model pembelajaran terintegrasi/terpadu. Fogarty (1991) melihatnya seperti kalaeidoskop, dimana pola-pola atau metode-metode baru menggunakan elemen-elemen dari dari setiap objek mata kuliah.

Fogarty menekankan perlunya team teaching dalam model ini. Sehingga bisa memadukan beberapa subjek dengan memprioritaskan konsep-konsep, keterampilan-keterampilan dari masing-masing subjek yang berbeda.

\section{HASIL DAN PEMBAHASAN}

Hasil observasi dan wawancara, terhadap pelaksanaan tiga matakuliah tersebut ditemukannya 3 permasalahan sebagai berikut.

\section{a. Komunikasi Dosen}

Permasalahan pertama ini ditemukan karena sesuai hasil wawancara dosen pengampu Bunpou dan Kaiwa (satu orang dosen), dan pengampu matakuliah Choukai tidak pernah mengkomunikasikan kemajuan atau hambatan dalam penyampaian materi. Menariknya lagi walaupun matakuliah Bunpou dan Kaiwa diampu oleh satu dosen yang sama, akan tetapi dalam pelaksanaannya dosen tersebut memberikan materi yang berbeda untuk matakuliah Bunpou dan Kaiwa.

Ketika dikonfirmasi kepada dosen pengampu mata kuliah tersebut, diketahui bahwa beliau tidak mengikuti konsep integrasi yang disepakati oleh Jurusan Bahasa Jepang. Menurut beliau hal ini dapat menyusahkan mahasiswa. Walaupun pada semester itu beliau mengajar Bunpou dan Kaiwa, akan tetapi konsep pembelajarannya tidak dibuat menjadi berintegrasi.

Dengan tidak dibuatnya menjadi terintegrasi maka komunikasi dosen pun terputus, sehingga setiap matakuliah terkesan berjalan 
sendiri-sendiri.

\section{b. Waktu dan Kegiatan Lain}

Waktu dan kegiatan lain juga mempengaruhi terjadinya integrasi antar matakuliah konten di bahasa Jepang. Seharusnya, Bunpou diberikan terlebih dahulu lalu dilanjutkan dengan matakuliah Kaiwa dan Choukai. Akan tetapi dalam pelaksanaannya, terjadi Choukai atau Kaiwa terlebih dahulu baru Bunpou. Hal ini dikeluhkan oleh mahasiswa karena pola kalimat seharusnya diperoleh terlebih dahulu melalui matakuliah Bunpou, baru dilatih pada matakuliah Choukai atau Kaiwa. Sehingga ketika Choukai atau Kaiwa terlebih dahulu diberikan, maka peran Bunpou menjadi berkurang. Hal ini disebabkan karena pada saat Choukai atau Kaiwa tersebut dosen harus memberikan pola kalimat baru sebelum dilatihkan. Hal ini juga membuat proses latihan pada dua matakuliah tersebut porsi waktunya menjadi berkurang. Waktu yang tidak sesuai dengan jadwal di sini disebabkan oleh banyaknya tanggal merah dan kegiatan lain dosen selain mengajar.

\section{c. Materi yang Berbeda}

Berkaitan dengan poin A dan B, pemberian materi kuliah dalam praktiknya sama antar kuliah, dan telah bersinergi. Akan tetapi pada matakuliah Kaiwa diberikan materi yang berbeda dari materi yang dikensepkan pada silabus hal ini bertujuan semata-mata untuk mengembangkan keahlian dari mahasiswa.

Menurut dosen pengampu matakuliah Kaiwa, diketahui bahwa ketika tidak menganut sistem terintegrasi maka pada matakuliah Kaiwa, dosen pengampu selain dapat melatih kemampuan berbicara dari mahasiswa juga dapat memberikan pola-pola kalimat yang tidak diajarkan pada perkuliahan Bunроu.

Di luar ketiga hasil tersebut, terdapat hasil angket mahasiswa yang menunjukan bahwa ketidakintergrasian dari matakuliah konten Bahasa Jepang memiliki sedikit pengaruh dalam hasil belajar, bahkan tidak mempengaruhi sama sekali.

Maka, dari hasil yang diperoleh tersebut diketahui bahwa dalam pelaksanaan pem- belajaran terintegrasi ditemukan permasalahan. Masalah-masalah ini dapat menyebabkan permasalahan lanjutan. Masalah yang harus ditangani, seperti berikut.

a. Bagi mahasiswa yang tidak lulus ada yang berpendapat, karena ia tidak memahami satu poin (contoh :partikel), maka ia tidak bisa memahami penggunaannya baik pada Kaiwa maupun Choukai.

b. Terdapatnya dosen pengampu yang berbeda antara Bunpou 1 dan Bunpou 2 menyebabkan mahasiswa harus mengulang lagi dalam menyesuaikan proses pembelajaran yang terjadi.

c. Tidak berjalannya integrasi antar matakuliah tidak serta merta menyebabkan mahasiswa menjadi susah dalam menerima matakuliah konten tersebut. Mahasiswa merasa dapat memperoleh kemampuan itu di luar dari perkuliahan, seperti film, lagu, dan berita. Dari sini dapat dilihat bahwa penerapan pembelajaran terintegrasi secara konseptual bagus untuk dijalankan akan tetapi secara pragmatis perlu diadakannya evaluasi yang mendalam dalam penerapannya.

\section{PENUTUP}

Dari pemaparan hasil dan pembahasan pada bagian sebelumnya, dapat disimpulkan bahwa pembelajaran terintegrasi pada Prodi Pendidikan Bahasa Jepang, Undiksha, telah berusaha untuk dijalankan, akan tetapi dalam praktiknya ditemukan sejumlah kendala. Kendala-kendala ini perlu dievaluasi lebih lanjut untuk keberlangsungan dari proses pembelajaran matakuliah konten tersebut. Dari hasil angket menunjukan bahwa mahasiswa merasa ketidakintegrasian matakuliah konten yang terjadi tidak mempengaruhi kemampuan dan penerimaan konten materi. Karena mahasiswa dapat mencarinya secara mandiri dari sumber lainnya.

\section{DAFTAR PUSTAKA}

Arifin, Zainal. 2010. Evaluasi Pembelajaran (Teori dan Praktik). Bandung. Makalah tidak 
diterbitkan.

Fogarty, Robin. 1991. Ten Ways To Integrate Curriculum. Skylight Publishing.

Munsilla, Veronica Boix. 2008. Integrative Learning:Setting the Stage for a Pedagogy of the Contemporary. Association A m e r i can Colleges and Universities NOAA. Designing Evaluation : For Education Project. Ilinois : Office of Education and Sustainable Development

Rusman. 2015. Pembelajaran Tematik Terpadu.

Jakarta : PT. Raja Grafindo Persada 